\title{
THE ROLES OF INSTITUTIONS IN FIGHTING AGAINST POVERTY
}

\author{
Surjono $^{1}$ \\ Diterima: 24 April 2015 \\ Disetujui: 26 Agustus 2015
}

\begin{abstract}
Decentralization and reformation in Indonesia have entered an uncertainty stage of people's welfare in the near future. Uncertainty of political stability and fluctuative oil prices also led to uncertainty of other dimensions of development. This paper aims to elaborate the roles of institution in reducing poverty and identify indicators to evaluate the performance of pro-poor development, particularly in Indonesian context. The method was literature reviews and specific case study. Sustainable development indicators were employed to evaluate an appropriate strategies by comparing with best practices in several local governments in Indonesia. This paper promotes steps in reducing poverty and provides indicators of pro-poor governance. The result of analysis shows that development planning at local government should have balanced strategies with focus on indicators to accelerate poverty reduction in the regions.
\end{abstract}

Keyword: poverty, decentralization, local-government

\section{Introduction}

Since promoted by Brundtland Commission(1987), most of sustainable development literatures agree on the three legs of sustainable development that incorporate economic, social, and environmental dimensions. Derived from this concept, authors promote principles for sustainable city development. Haughton and Hunter (2005), as an example, proposed three principles for sustainable development in city: inter-generational equity, social justice, and trans-frontier responsibility principles. Other author promoted the three legs of poverty reduction within the framework of sustainable development, i.e. economy, poverty, and environment (Surjono \& Peterson, 2010). Cities become the focus of sustainable development since more population live in urban areas, gross national products were produced mainly in cities, and productive farmland is converted to urban uses. Other issues such as dependency on oil and car, water demand and waste production worsened urban environment.

Issues on energy infrastructure and climate change are becoming more important in developing countries. The price of oil is the most sensitive to the poor, while climate change affects mostly the livelihood of farmers and fishermen. The need for energy poverty alleviation for the next 20 years should be balanced with reducing $7 \%$ energy consumption of individuals, but still, increase $0.13^{\circ} \mathrm{C}$ global temperature(Chakravarty \& Tavoni, 2013). Related to the live of poor farmers, recent research have been addressed to agriculture and rural development, such as the work of Bellon, et al., (2005) and Farrow, Larrea, Hyman, \& Lema(2005). These articles can conclude that poverty reduction policy is closely related to governance of energy infrastructure and ecosystem services.

\footnotetext{
${ }^{1}$ Faculty of Engineering, University of Brawijaya
} 
Based on the concept that the balance of three legs of sustainable development as well as the three legs of poverty reduction are influenced and enabled by the institution, then, institutional development becomes endogenous determinant in poverty reduction strategy. Indonesia has achieved MDGs for institutional development (Gaiha, Imai, \& Nandhi, 2009). However, Indonesia must catch up the achievement of the neighbouring countries since the rank was still below average of East/South East Asian Countries. Main components that empirically reduced poverty are infrastructures and formal credit expansion which are the domain of institutional governance, particularly the government(World Bank, 2010).

Good governance has become the key in resolving poverty. World Bank (1999) published governance indicators in socio-political domain that promoted three sets of governance indicators, i.e., government effectiveness, rule of law and graft. Indonesia has seriously fought corruption and graft at governmental institutions. Commission to fight against corruption had been established in SBY's administration period. We do not discuss corruption and graft in this paper. This article focuses on the roles of instituion at the local level, with the first objective isto identify good practices of government's policies that reduce poverty. The second objective is to propose indicators/parameters of development performance at the local level which are pro-poor.

\section{Pro-Poor Development Indicators}

Since 2001 the province of East Java had initiated a set of povertyindicators that was based on asset framework criteria.The main criteria within the set of indicatoers are food consumption, clothing, shelter, and others (e.g. the sources of income and health service provision).These criteria of indicators was formulated to establish a concensus among related institutions (Central Body of Statistics, Social Affairs Office, Health Affairs Office, and National Family Planning Coordination Board)(The Government of East Java Province, 2001). By these indicators, more real picture of poverty can be captured to set effective development strategies and programs particularly related to poverty reduction.

Jawapos, also since 2001, initiated an activity to capture achievement of local governmentsin showing their commitment and creating creativity and inovation in urban management. The Jawa Pos Institute of Pro-Autonomy (JPIP), a semi autonomous institute, sets 3 parameters to measure the performance of the management: economic, public services, and local political parameters. There are three indicators in economic parameters: economic growth, economic distribution, and local economic empowerment. There area also three indicators within public services parameter: education, health, and administration services, while in the local political parameter JPIP uses two indicators which are public participation and accountability(UNfGI, 2014). The main award (golden trophy), therefore, is classified into three performances based on the three parameters. The award, then, can be sub classified into (15) fifteen special fields (silver trophy) that comprises educational services, health services, administration services, economic growth, economic distribution, public accountability, public participation, reduction of maternal and infant mortality, promotive and preventive health activities, creative and rehabilitative health service improvement, environmental management, community based total sanitation, economic development, public services, and political performance. Other nongovernment initiatives, similar to JPIP, is the Fajar Institute of Pro-Otonomi (FIPO), while government initiatives are BKPM investment award and Innovation Government Award (IGA).

Related to development parameters that are pro-poor, MDGs award perhaps is closer to poverty reduction. MDGs award has 4 main general categories, i.e., nutrition, maternal and infant health, access to clean water and basic sanitation, HIV/AIDS and other infectious decease. MDGs award also has four specific categories: budget allocation for 
MDGs, MDGs program sustainability, impacts of MDGs on community, and best MDGs innovation for youth (CISDI, 2014). In the post 2015 period Indonesia's MDGs are targeted to 12 goals: ending up poverty, empowerment of women and gender equity, qualified and long live education, ensure a healthy life, ensure food security and good nutrition, achieve universal access to water and sanitation, ensure sustainable energy, creating sustainable employment and equitable growth, managing natural resources in a sustainable manner, good governance and effective institution, ensure stable and peaceful community, and lastly creating a global enabling environment and encourage long-term financial.

MDGs programs are supported by various actors at the local level, including government, non-government, private sectors, society, and youth organization. In terms of fighting against hunger and poverty, most activities were distributed in Sumatra, Java, Nusa Tenggara and Papua. The actors of activities in the first goal of MDGs varied among NGO, private sectors, and mix between actors. In fighting against hunger and poverty, the roles of private sectors were dominant in Java, Sumatra, and Nusa Tenggara Timur, while NGOs were dominant in Papua and Sumatra. To be noted here, that government did not have important role in the achievement of Goal 1 of MDGs (CISDI, 2014).

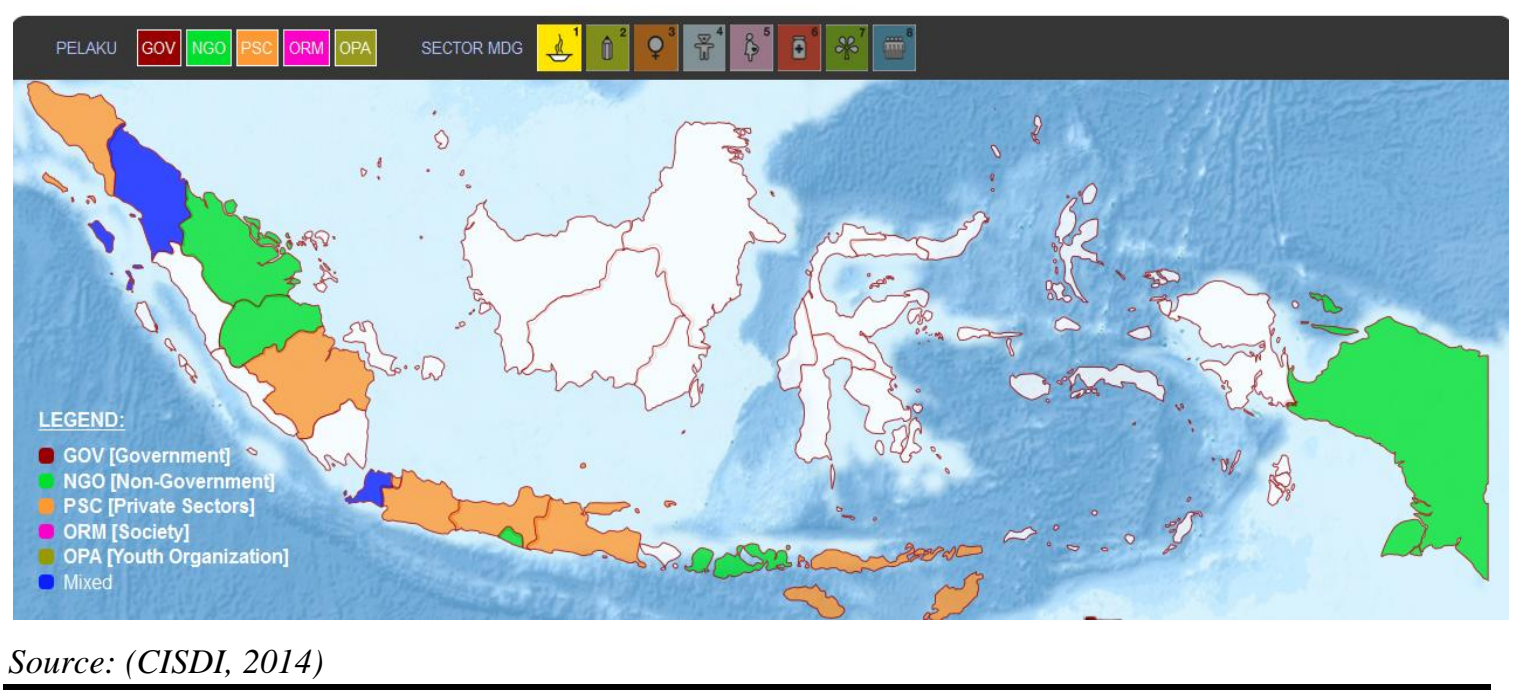

Figure 1. Map of Efforts to Achieve Goal 1 of MDGs

\section{Good Practices}

The roles of the Government, the Provincial Governments, and the Local Governments are actually very significant in providing initiatives and facilities for other development actors to give more contribution in the national - local development. Government should play it roles as initiator and facilitator in creating an enabling environment for empowerment and growth of all forms of capital.

Several initiations and inovations that were promoted by the Local Governments in 2014 and have created good enabling environment are selected as follows. Twelve heads of local governments were selected to identify their initiation and inovation in developing their regions and to see how they match to JPIP's criteria. Those 12 local governments are Siak Regency, Hulu Sungai Tengah Regency, Bengkulu Utara Regency, Maluku Tengah Regency, Kudus Regency, Boalemo Regency, Pamekasan Regency, Banjar Regency, Tuban Regency, Kendari Municipality, Batu Municipality, and Kotawaringin Barat Regency. 
Table 1. Inovative governance at the local level by the Local Government

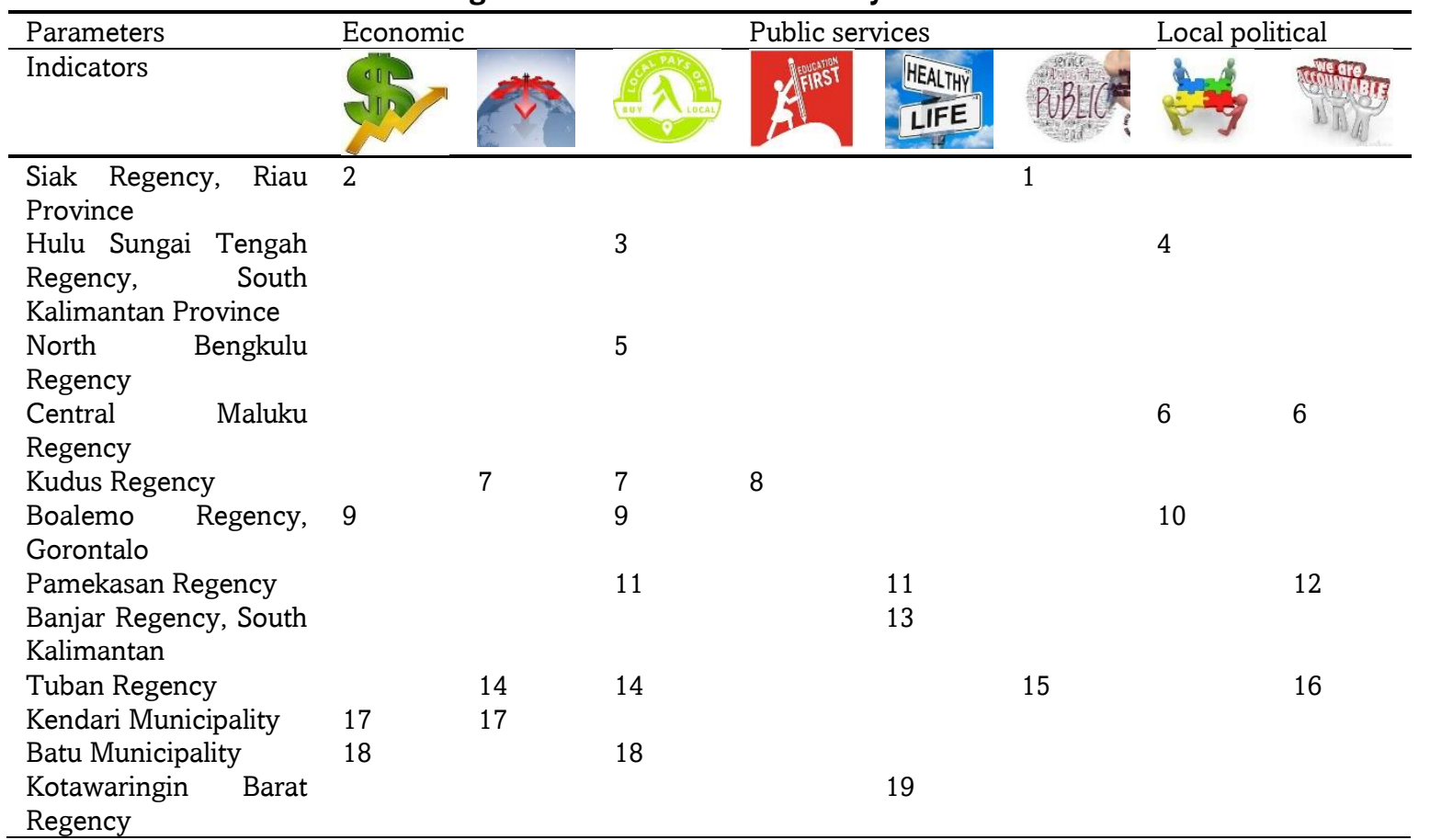

Note:

1. Pelayanan administrasi terpadu kecamatan (Paten): integrated administration services

2. Paten has accelerated investment. BKPM investment award

3. Improving local economy by replacing coal mining with rice field

4. Public participation in agricultural and infrastructure development. Has achieved poverty and unemployment reduction

5. Growing local economy by improving fishery and developing an integrated town Kota Terpadu Mandiri (KTM) Lagita

6 Tabaos Masohi Menata Negeri: based on local cosmology that encourage the regent (tabaos) to directly involve / work with the people. Awarded a best regional planning in 2013 and 2014.

7 Changing people's mindset from labor to entrepreneurship

8 Improving both gross and net participation in education ( $A P K$ and $A P M$ )

9 Successful in developing $K T M$ and cocoa plantation

10 Incorporating Arm Forces in building infrastructures

11 Successful in aleviating the region from 'left behind region' status

12 Program Pugar (2014)

13 Converting domestic waste to become electricity and gas.

14 Changing mindset from farmer to entrepreneur

15 Free Birth Certificate service

16 Accountable report (BPK audit)

17 Develop isolated regions through infrastructure with minimal budget

18 Merging tourism and organic agriculture

19 Puting health and environment as local priority

20

Table 1 shows that inovations and initiatives for beter future have been implemented in various region. The table also shows that the priority of each region (read: bupati of mayor) were different. All programs were directly influence poverty reduction in the regions, however, only few programs were directly targetted to reduce poverty. Some real programs that are related to poverty reduction effort are: 1) Productivity/employment: changing people's mindset to entrepreneurship; 2) economic governance: rural development (agriculture and fishery); 3) education and health; 4) environment; and 5) 
participation.The most important steps, then, are to disseminate good practices and form them into structural mechanism of governance at the national to local levels.

\section{The Proposed Framework}

Based on the empirical practices of good governance in fighting against poverty at the local government level, I propose indicators of pro-poor development performance as follows (figure 2).

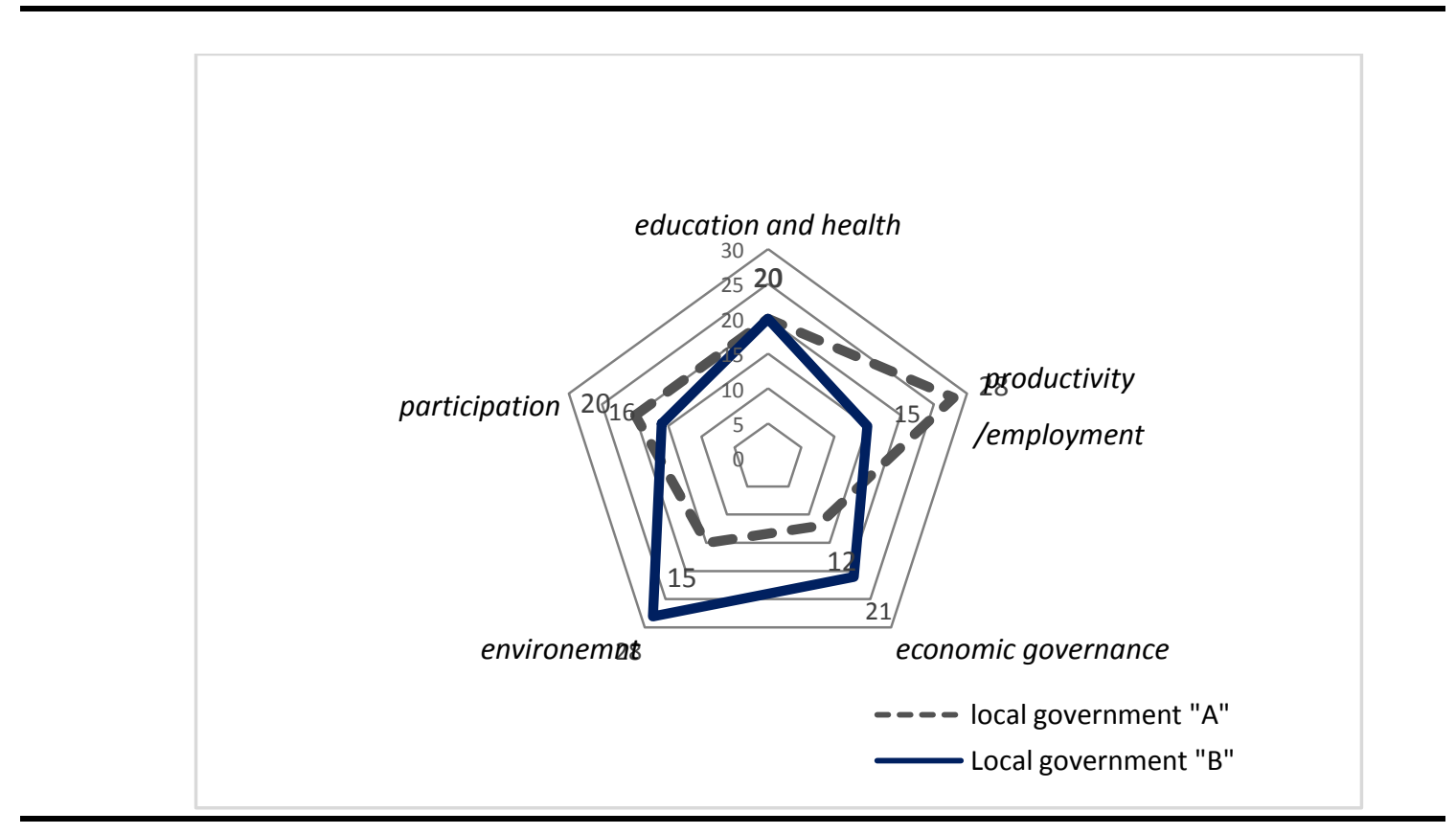

Figure 2. Indicators of Pro-Poor Development Performance in Indonesia

\section{Conclusion}

If development is targetted to aleviate poverty in Indonesia, then the most representative of pro-poor development indicators must be established and should become national concensus. MDGs indicators are the most suitable set of development indicators that respond the global goal to reduce poverty. Public initiatives, such as JPIP otonomy award, have contributed to the creation of general indicators of local development. Similar award, to mention a few, such as FIPO (the Fajar Institute of Pro Otonomi) award and Innovation Government Award (IGA) have accelerated the 'road' to building better roles of institution (government) for better future of Indonesia, particularly in our efforts to aleviate poverty from the nation. These non-government organization's initiations should have cross-reference with the MDGs to effectively reduce poverty with the support of local institutions and other local stakeholders.

\section{References}

Bellon, M. R., Hodson, D., Bergvinson, D., Beck, D., Martinez-Romero, E., \& Montoya, Y. (2005). Targeting agricultural research to benefit poor farmers: Relating poverty mapping to maize environments in Mexico. Food Policy, 30, 476-492.

Chakravarty, S., \& Tavoni, M. (2013). Energy poverty alleviation and climate change mitigation: Is there a trade off? Energy Economics, 567-573. 
CISDI. (2014, March 1). Center for Indonesia's strategic development strategies. Diambil kembali dari CISDI: http://cisdi.org

CISDI. (2014, March 1). CISDI. Diambil kembali dari Pemetaan dari Progam MDG: http://mapping.cisdi.org/

Farrow, A., Larrea, C., Hyman, G., \& Lema, G. (2005). Exploring the spatial variation of food poverty in Ecuador. Food Policy, 510-531.

Gaiha, R., Imai, K., \& Nandhi, M. A. (2009). Millennium Development Goal of Halving Poverty in Asia. Journal of Asian and African Studies, 44(2), 215-237.

Haughton, G., \& Hunter, C. (2005). Sustainable Cities. London: Routledge.

Surjono, \& Peterson, A. (2010). Constructing a New Planning Indicator Framework to Reduce Poverty in Indonesia. Journal of Mathematics and Technology.

The Government of East Java Province. (2001). East Java Poverty Identification by the New Indicators. Surabaya: BPS.

UNfGI. (2014, March 1). University Network for Governance Inovation. Diambil kembali dari Fisipol UGM: http://igi.fisipol.ugm.ac.id/index.php/id/jpip-otonomi-awards

World Bank. (1999). Our Common Journey: A Transition Toward Sustainability. Washington: National Academy Press.

World Bank. (2010). How Infrastructure and Financial Institutions Affect Rural Income and Poverty: Evidence from Bangladesh. Journal of Development Studies, 46(6), 1109-1137.

World Commission on Environment and Development (WCED). (1987). Our Common Future. Oxford: Oxford University Press. 